\title{
Introduction of TAIGA Concept
}

\author{
Tetsuro Urabe, Jun-ichiro Ishibashi, Michinari Sunamura, Kyoko Okino, \\ Ken Takai, and Katsuhiko Suzuki
}

\begin{abstract}
After the discovery of seafloor hydrothermal venting, it became evident that the subseafloor fluid advection system plays an extremely important role in the Earth's element cycle. We designate these fluid advections as sub-seafloor TAIGAs (which stand for Trans-crustal Advection and In-situ biogeochemical processes of Global sub-seafloor Aquifers. In Japanese, "taiga" refers to "a great river"). This concept emphasizes dynamic signature of subseafloor hydrosphere, especially for a hydrothermal fluid circulation system that might support subseafloor microbial ecosystem. However, the link between the fluid advection and microbial activity has never been clearly demonstrated. We therefore hypothesized four types of sub-seafloor TAIGAs; hydrogen, methane, sulfur, and iron to investigate the relation. Each type of TAIGA is characterized by the most dominant reducing substance available for chemosynthesis. Our trans-disciplinary research between 2008 and 2012 indicates that the hypothesis is valid and the microbial activity within the flow of TAIGAs has strong linkage to chemical characteristics of each TAIGA; that is, the subseafloor TAIGA supplies four different kinds of electron donor for respective chemolithoautotroph ecosystem which is suitable for particular electron donor. It is also shown that the composition of dissolved chemical species in the subseafloor TAIGAs are substantially affected by the geological background of their flow path such as volcanism, surrounding host rocks and tectonic settings. Our research clearly indicates that the chemosynthetic sub-seafloor biosphere is controlled and supported by Earth's endogenous flux of heat and mass beneath the seafloor.
\end{abstract}

\section{Keywords}

Arc-backarc system - Chemosynthesis - Global heat and mass flux • Hydrothermal activity $\bullet$ Mid-ocean ridge $\bullet$ Oceanic crust $\bullet$ Subseafloor biosphere

T. Urabe $(\varangle) \cdot$ M. Sunamura

Department of Earth and Planetary Science, Graduate School of

Science, The University of Tokyo, Tokyo 113-0033, Japan

e-mail: urabe@eps.s.u-tokyo.ac.jp

J.-i. Ishibashi

Department of Earth and Planetary Sciences, Faculty of Sciences,

Kyushu University, Fukuoka 812-8581, Japan

K. Okino

Atmosphere and Ocean Research Institute, The University of Tokyo,

Kashiwa, Chiba 277-8564, Japan
K. Takai

Department of Subsurface Geobiological Analysis and Research (D-SUGAR) and Research and Development (R\&D) Center for Submarine Resources, Japan Agency for Marine-Earth Science and Technology (JAMSTEC), Yokosuka, Kanagawa 237-0061, Japan

\section{K. Suzuki}

Institute for Research on Earth Evolution (IFREE) and Precambrian Ecosystem Laboratory (PEL), Japan Agency for Marine-Earth Science and Technology (JAMSTEC), Yokosuka, Kanagawa 237-0061, Japan 


\subsection{Subseafloor Biosphere and Hydrosphere}

The finding of unique macrobenthos community around deep-sea hydrothermal vent sites in the late 1970s attracted a lot of attention among various scientists. The high biomass density indicates that the hydrothermal site is one of the most dynamic and productive ecosystems on the earth (Childress and Fisher 1992; Fisher et al. 2007). The ecosystem is believed to be sustained by primary production of chemolithoautotrophic microbes, partly symbiotic, which produce organic compounds through chemosynthesis using chemical energy of inorganic materials dissolved in hydrothermal fluids. The high primary production based on these reactions demolishes the traditional idea that all organisms living on the earth depend solely on the photosynthesis using sunlight. In the sulfide chimney structure of the vents, various chemolithoautotrophic microbes were found both under various redox and thermal conditions (Deming and Baross 1993; Takai and Horikoshi 1999; Kelley et al. 2002). These findings suggest that the microbial ecosystem would be developed extensively beneath the seafloor, if there exists sufficient permeability within the oceanic crusts.

Such a hypothesis is supported by an observation that significant amount of water may exist within the oceanic crust (e.g., Johnson et al. 2006). The compilation of the measured porosity of the oceanic crust indicates that the values are up to $34 \%$ in the young oceanic crust and higher than $10 \%$ even in altered crust older than $10 \mathrm{Ma}$ (Johnson and Pruis 2003). The total mass of water below the seafloor was estimated to be $26 \times 10^{18} \mathrm{~kg}$, which corresponds to $\sim 2 \%$ of that of the entire mass of seawater. This size is much larger than that of continental groundwater, and comparable to that of ice on the polar regions (Mottl et al. 2007).

As a first-order approximation, the type of fluid advection system could be estimated by the thermal regime of the seafloor. According to the thermal model calculations (e.g., Stein and Stein 1992), heat discharge through the seafloor is classified into three categories; high-temperature hydrothermal fluid advection at the axial region of midoceanic ridge, low-temperature hydrothermal fluid circulation at the ridge flank region where there is impermeable sediment cover, and conductive cooling through the surface of the oceanic crust. At the ridge axis whose crustal age is younger than $1 \mathrm{Ma}$, the axial magma chamber is the most important heat source to drive high-temperature fluid circulation. Global heat flux through the ridge axes is estimated as $(1.5-2.8) \times 10^{12} \mathrm{~W}$ from crust formation rate along all the ridge axes on the earth (Mottl 2003). And this heat flux corresponds to water mass flux of (3.1-5.9) $\times 10^{16} \mathrm{~g} / \mathrm{year}$, assuming the temperature of the hydrothermal fluid is $350{ }^{\circ} \mathrm{C}$ (Mottl 2003). On the other hand, the heat generated from cooling of the lithosphere is dominant at the ridge flank regions. Heat flux at the ridge flank region is as large as (5.1-9.1) $\times 10^{12} \mathrm{~W}$, considering the temperature of the oceanic crust to be $10-40{ }^{\circ} \mathrm{C}$ (Johnson and Pruis 2003). Because the heat in the ridge flank is transported by low temperature fluid $\left(5-20{ }^{\circ} \mathrm{C}\right)$, estimated water mass flux should be as large as $(0.2-2.0) \times 10^{19} \mathrm{~g} /$ year (Mottl 2003). This estimation leads to a conclusion that mass flux of the ridge flank region is much larger than that of the ridge axis region, and comparable to the total water flux of terrestrial rivers $\left(=3.74 \times 10^{19} \mathrm{~g} /\right.$ year $)$. Such advective flow in the ridge flank region was confirmed at seamounts located in the eastern flank of the Juan de Fuca ridge where low temperature fluid advection has been observed by submersible dives and ODP/IODP drillings (Fisher et al. 2003).

Estimation of global geochemical flux transported through the seafloor is a more difficult problem and was tackled with two different approaches (e.g., Alt 2003). One approach is a calculation by multiplying the chemical composition of the venting fluids and the estimated water mass flux (e.g., Elderfield and Schultz 1996). The major source of uncertainty in this approach comes from the fact that the contribution of the mass flux by the low temperature hydrothermal fluid at the ridge flank could not be taken into account. The limited information on the chemistry of circulating fluid in the ridge flank region revealed that the low temperature hydrothermal fluid showed different chemistry from that of the high temperature fluid from the axial area (Mottl et al. 1998). For example, the low temperature fluid acts as sink for alkali elements $(\mathrm{Na}, \mathrm{K}$, and $\mathrm{Li})$ and some nutrients $\left(\mathrm{NO}_{3}, \mathrm{PO}_{4}\right)$ in addition to $\mathrm{Mg}$ and $\mathrm{SO}_{4}$ ions. Besides, the data on minor components are missing especially for the low temperature fluids.

The other approach is a calculation based on geochemical budget during alteration process of the oceanic crust (e.g., Bach et al. 2003). The difference in chemical composition between the fresh and altered oceanic crusts was integrated to estimate net elemental supply to and removal from the oceanic crust by the advective fluids. Although estimated fluxes from these two approaches still show large discrepancy, these efforts shed light on global geochemical flux by advective flow beneath the seafloor. It is suggested that the hydrothermal flux is comparable for several major and minor elements to that of river run off on the continent (Wheat and Mottl 2004). In addition, the hydrothermal fluid circulation within the oceanic crust, including low-temperature fluid advection and the rock alteration were considered to affect on the whole-earth-mantle dynamics by regulating the cool process of the Earth.

There is no doubt that the subseafloor fluid advection plays an extremely large role in the Earth's element cycle especially for fluid-mobile elements. However, it is not clear whether the fluid is also responsible or not for the existence 
of so-called deep biosphere through lithochemoautotrophic metabolism. So we would like to further investigate this possibility.

\subsection{Hydrothermal Systems as a Window of Sub-seafloor TAIGAs}

We propose to designate these hydrothermal fluid advections as sub-seafloor TAIGAs (which stand for Trans-crustal Advection and In-situ biogeochemical processes of Global sub-seafloor Aquifers. In Japanese, "taiga" refers to "a great river"). This name emphasizes dynamic signature of subseafloor hydrosphere. Fluid chemistry of the advective flow would be controlled by the similar processes to rivers on land, which may change their chemistry gradually along the pathway. Sub-seafloor TAIGAs have a wide range of inputs and outputs including exchange components with the earth's crust through hydrothermal alteration, dissolution and precipitation of materials en route, and interactions with biosphere in their watershed areas.

Although wide variety of driving forces have been proposed for fluid advections beneath the seafloor, such as, tectonic compaction, hydraulic head, and decomposition of hydrate (Ge et al. 2003), thermally-generated density contrasts driven by a heat source such as magma chamber along the mid-ocean ridges undoubtedly induces the most dynamic fluid advection. As magma intrusion causes high temperature environment, seawater becomes more reactive with the surrounding rocks such as mid-ocean ridge basalt (MORB). Besides, degassing of $\mathrm{CH}_{4}, \mathrm{CO}_{2}, \mathrm{CO}$, and $\mathrm{H}_{2}$ from the magma would significantly increase the geochemical flux of several chemical species and be transported by hydrothermal fluid circulation, which fuels ecosystems in active subseafloor TAIGAs. Moreover, the high-temperature hydrothermal fluid vented at "river mouth" mixes with the ambient seawater as it rises, to form hydrothermal plumes, which could host another regime of chemolithoautotrophic microbes.

Apart from the axial region of the mid-oocean ridges, diversity in fluid chemistry has been recognized in association with the findings of seafloor hydrothermal systems in various tectonic settings (e.g. Gamo et al. 2006; Seyfried et al. 2004). Fluid chemistry is basically controlled by hydrothermal interactions with surrounding rocks, which means the chemical signature of the rocks is an important factor for the diversity. Difference in elemental concentrations would be more obvious in minor species such as B, Cs, As, Sb and other fluid-soluble (or fluid-mobile) incompatible elements, which are difficult to be fixed into alteration minerals during high-temperature fluid-rock interactions. Fluid chemistry is affected also by various materials encountered during the fluid circulation, such as magmatic volatiles from the heat source magma and/or organic matter accumulated in sediment around the hydrothermal system. They supply chemical species which control $\mathrm{pH}$ of the fluid by dissolution (such as $\mathrm{CO}_{2}$, $\mathrm{SO}_{2}, \mathrm{HCl}, \mathrm{H}_{2} \mathrm{~S}$ ) or oxic-reductive state (such as $\mathrm{H}_{2} \mathrm{~S}, \mathrm{H}_{2}$ ) when dissolved in the fluid. Moreover, some of these species are also important energy source for microbiological metabolism, as will be discussed later.

It should be pointed out that the estimation of geochemical flux does not consider contributions and diversity of the hydrothermal systems in the arc-backarc setting. Baker et al. (2008) estimated that submarine volcanoes in intraoceanic arcs could supply a hydrothermal discharge equal to $10 \%$ of that from the global mid-ocean ridge, based on combining the statics from their studies on Tonga-Kermadec Arc and Mariana Arc. They also emphasized the geochemical impact may be even more significant, since many chemical species are often more highly concentrated in arc fluids than in midocean ridges fluids. Variations of chemical species in hydrothermal fluids may directly affect microbial metabolism and subsequent vent macrofauna. A major re-examination for estimation for geochemical flux is required.

\subsection{Diversity of Subseafloor TAIGAs}

In order to understand linkage between the microbial activity and chemical characteristics of hydrothermal and advective flows, we propose four types of sub-seafloor TAIGAs. Each type of TAIGA is characterized by the most dominant reducing substance available for different chemosyntheses.

For example, if we focus on elemental cycles of carbon, variety of carbon fixation processes and, on the other hand, processes converting organic carbon to inorganic carbon (mineralization) have been recognized to occur within active hydrothermal systems. There are two important mechanisms to fix carbon to organic species; primary biomass production by microbial chemosynthesis and a non-biological process (Fischer-Tropsch-type reaction). The latter reaction, which synthesizes hydrocarbons and other organic matter from $\mathrm{CO}_{2}$ and $\mathrm{H}_{2}$, is known to occur under the high-temperature hydrothermal conditions that result from processes such as serpentinization of olivine, based on experimental studies (e.g., McCollom and Seewald 2001).

The known metabolic reactions used by chemosynthetic microbes are listed in Table 1.1. The metabolism of microorganisms in the subseafloor biosphere can be expressed as a reaction between a reducing substance (electron donor) and an oxidant (electron acceptor) (McCollom and Shock 1997). To categorize wide ranges of the chemosynthetic metabolic reactions, we take notice of major reducing substances (electron donors); that is, hydrogen, methane, sulfur, and iron as the primary reducing substances that serve as energy source. Within each type of TAIGAs, chemolithoautotrophic 
Table 1.1 Known redox reactions associated with chemolithoautotrophic microbes in a deep-sea hydrothermal vent environment (modified after Fisher et al. 2007)

\begin{tabular}{lll}
\hline Reductant & Oxydant & Chemical reaction \\
\hline Hydrogen & Oxygen & $2 \mathrm{H}_{2}+\mathrm{O}_{2} \rightarrow 2 \mathrm{H}_{2} \mathrm{O}$ \\
\hline Hydrogen & Ferric compounds & $\mathrm{H}_{2}+2 \mathrm{Fe}^{3+} \rightarrow 2 \mathrm{Fe}^{2+}+2 \mathrm{H}^{+}$ \\
\hline Hydrogen & Sulfate & $4 \mathrm{H}_{2}+\mathrm{SO}_{4}{ }^{2-}+2 \mathrm{H}^{+} \rightarrow \mathrm{H}_{2} \mathrm{~S}+4 \mathrm{H}_{2} \mathrm{O}$ \\
\hline Hydrogen & Carbon dioxyde & $4 \mathrm{H}_{2}+\mathrm{CO}_{2} \rightarrow \mathrm{CH}_{4}+2 \mathrm{H}_{2} \mathrm{O}$ \\
\hline Hydrogen & Native sulfur & $\mathrm{H}_{2}+\mathrm{S}^{0} \rightarrow \mathrm{H}_{2} \mathrm{~S}$ \\
\hline Hydrogen & Nitrate & $5 \mathrm{H}_{2}+2 \mathrm{NO}_{3}{ }^{-}+2 \mathrm{H}^{+} \rightarrow \mathrm{N}_{2}+6 \mathrm{H}_{2} \mathrm{O}$ \\
\hline Methane & Oxygen & $\mathrm{CH}_{4}+2 \mathrm{O}_{2} \rightarrow \mathrm{CO}_{2}+2 \mathrm{H}_{2} \mathrm{O}$ \\
\hline Methane & Sulfate & $\mathrm{CH}_{4}+\mathrm{SO}_{4}{ }^{2-} \rightarrow \mathrm{HCO}_{3}{ }^{-}+\mathrm{HS}^{-}+\mathrm{H}_{2} \mathrm{O}$ \\
\hline Sulfide & Oxygen & $\mathrm{HS}^{-}+2 \mathrm{O}_{2} \rightarrow \mathrm{SO}_{4}{ }^{2-}+\mathrm{H}^{+}$ \\
\hline Native sulfur & Oxygen & $2 \mathrm{~S}^{0}+2 \mathrm{H}_{2} \mathrm{O}+3 \mathrm{O}_{2} \rightarrow 2 \mathrm{SO}_{4}{ }^{2-}+4 \mathrm{H}^{+}$ \\
\hline Thiosulfate & Oxygen & $\mathrm{S}_{2} \mathrm{O}_{3}{ }^{2-}+2 \mathrm{O}_{2}+\mathrm{H}_{2} \mathrm{O} \rightarrow 2 \mathrm{SO}_{4}{ }^{2-}+2 \mathrm{H}^{+}$ \\
\hline Sulfide & Nitrate & $10 \mathrm{HS}^{-}+4 \mathrm{H}^{+}+14 \mathrm{NO}_{3}{ }^{-} \rightarrow 10 \mathrm{SO}_{4}{ }^{2-}+7 \mathrm{~N}_{2}+2 \mathrm{H}_{2} \mathrm{O}$ \\
\hline Native sulfur & Nitrate & $5 \mathrm{~S}^{0}+2 \mathrm{H}_{2} \mathrm{O}+6 \mathrm{NO}_{3}{ }^{-} \rightarrow 5 \mathrm{SO}_{4}{ }^{2-}+4 \mathrm{H}^{+}+3 \mathrm{~N}_{2}$ \\
\hline Thiosulfate & Nitrate & $5 \mathrm{~S}_{2} \mathrm{O}_{3}{ }^{2-}+8 \mathrm{NO}_{3}{ }^{-}+\mathrm{H}_{2} \mathrm{O} \rightarrow 10 \mathrm{SO}_{4}{ }^{2-}+2 \mathrm{H}^{+}+4 \mathrm{~N}_{2}$ \\
\hline Ferrous compounds & Oxygen & $4 \mathrm{Fe}^{2+}+\mathrm{O}_{2}+4 \mathrm{H}^{+} \rightarrow 4 \mathrm{Fe}^{3+}+2 \mathrm{H}_{2} \mathrm{O}$ \\
\hline Ferrous compounds & Nitrate & $10 \mathrm{Fe}^{2+}+2 \mathrm{NO}_{3}{ }^{-}+12 \mathrm{H}^{+} \rightarrow \mathrm{N}_{2}+10 \mathrm{Fe}^{3+}+6 \mathrm{H}_{2} \mathrm{O}$ \\
\hline Nitrite & Oxygen & $2 \mathrm{NO}_{2}{ }^{-}+\mathrm{O}_{2} \rightarrow 2 \mathrm{NO}_{3}{ }^{-}$ \\
\hline Ammonia & Oxygen & $2 \mathrm{NH}_{3}+3 \mathrm{O}_{2} \rightarrow 2 \mathrm{NO}_{2}{ }^{-}+2 \mathrm{H}^{+}+2 \mathrm{H}_{2} \mathrm{O}$ \\
\hline
\end{tabular}

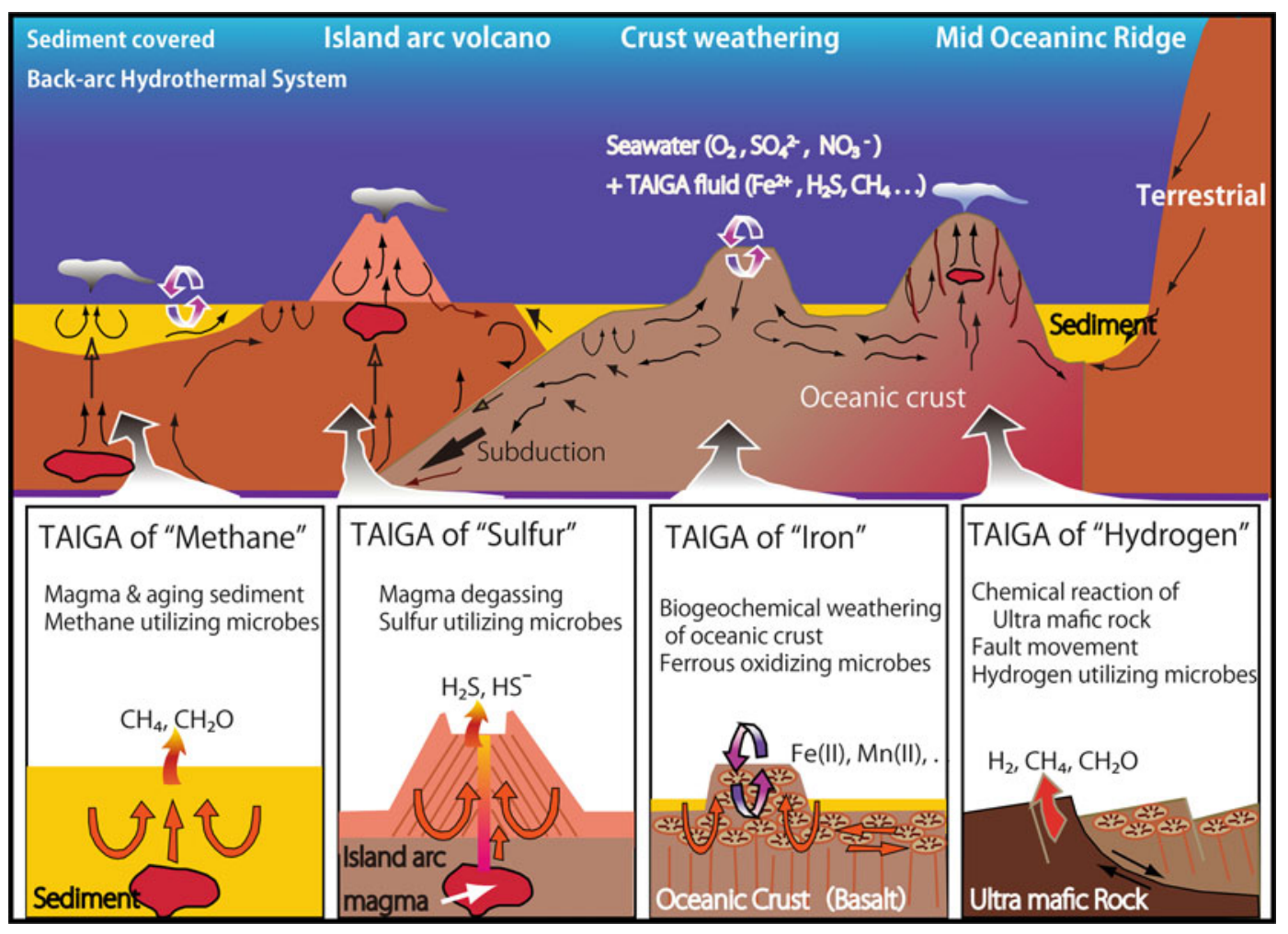

Fig. 1.1 Schematic model of four types of subseafloor fluid advection system (TAIGA). Fluid chemistry reflects tectonic and magmatic activities of the seafloor and controls chemosynthesis of subseafloor biosphere

metabolism is represented by an activity of following microorganisms; hydrogen oxidizers including methanogens, methan oxidizers such as methanotrophs, sulfur oxidizers, and, iron and manganese oxidizers.

As terrestrial rivers supply nutrients and essential elements to the ecosystem developed along the watershed areas, subseafloor TAIGAs supply electron donors for chemolithoautotroph ecosystems in active hydrothermal systems. Flow pathways and dissolved chemical species of the subseafloor TAIGAs are strongly affected by the geological background such as surrounding host rocks and tectonic settings (Fig. 1.1). In the following paragraphs, expected 
linkage among the microbial activity, fluid chemistry, and geological background of hydrothermal systems in each type of TAIGA is outlined.

\subsubsection{TAIGA of Hydrogen}

In 2004, hydrogen-based methanogenic-microbial ecosystem is proposed beneath the seafloor of the active hydrothermal field in the Central Indian Ridge by Takai et al. (2004a). They called this ecosystem the hyperthermophilic SLiME or "HyperSLiME", after the name of SLiME (subsurface lithoautotrophic microbial ecosystem), which had been proposed by Stevens and McKinley (1995) for bacteria found in a deep well in flood basalt sequences in Columbia River valley. Takai et al. (2004b) strongly suggested that the hydrogenotrophic methanogenesis reaction was actively taking place based on the evidence of high concentration of $\mathrm{H}_{2}$ in the hydrothermal fluid and rich in $\delta^{13} \mathrm{C}$-depleted $\mathrm{CH}_{4}$ that is interpreted as results of the microbial consumption and/or the methanogenic archaeal production. The $\mathrm{CH}_{4}$ generated by methanogens becomes to be an important electron donor for the methane oxidizers at the seafloor.

Similar microbiological and geochemical evidence for hydrogen oxidation have also been found at the Mariner Field of the Lau Basin (Takai et al. 2008a), Suiyo Seamount of the Izu-Bonin arc (Toki et al. 2008), Logatchev Field of Mid Atlantic Ridge (Petersen et al. 2011), and other locations (Takai et al. 2005), and it is believed that this phenomenon can be seen in a broad range of hydrothermal vents (Takai et al. 2004a). The key point of this TAIGA is the high concentration of $\mathrm{H}_{2}$ which is the most reductive substance on the Earth and the ultimate electron donor. These lines of evidence strongly suggest that this metabolism may occur even in the Earth's lower crust where the redox state is lower than that of the upper crust, and this biogeochemical processes also affects microbial ecosystems such as methanotrophy which may exist in shallower environment of higher redox states. It is also pointed out that the hydrogen oxidizing hyperthermophiles occupy the deeprooted position on the evolutionary tree that is close to the common ancestor of all life forms (Takai et al. 2008b). Therefore, this metabolism may be the oldest on the Earth and also occupy the most fundamental position in the present-day chemolithoautotrophic communities.

The most notable source of $\mathrm{H}_{2}$ in hydrothermal fluid is serpentinization reaction in ultramafic rocks during the hydrothermal alteration (Charlou et al. 2002; Nakamura et al. 2009). TAIGA of hydrogen is expected to occur in a tectonic setting of slow or ultra-slow spreading ridge where outcrop of ultramafic rocks is often observed. Exhumation of ultramafic rocks is closely related to the block movements along faults and the fluid circulation in TAIGA of hydrogen is caused by heat mined from lower crust/upper mantle along the faults. Besides, mechanochemical production of $\mathrm{H}_{2}$ associated with fault movement has been proposed (e.g., Hirose et al. 2011). In other words, it is indicated from experiments that physically broken mineral surfaces react with $\mathrm{H}_{2} \mathrm{O}$ to generate $\mathrm{H}_{2}$. Another important source of $\mathrm{H}_{2}$ is thermal decomposition of organic matter during fluidsediment interaction (Kawagucci et al. 2013). Such interaction is expected to occur in a hydrothermal system which is hosted within thickly accumulated sediment. However, the extent of $\mathrm{H}_{2}$ enrichment in sediment-associated systems is not so significant compared with that in ultramafic rockhosted system.

\subsubsection{TAIGA of Methane}

Hydrothermal fluids of sediment-associated systems are often characterized by enrichment in $\mathrm{CH}_{4}$. Concentration of $\mathrm{CH}_{4}$ in a sediment-associated hydrothermal system is basically two or three orders higher than that of sedimentstarved hydrothermal system. In TAIGA of methane, abundant $\mathrm{CH}_{4}$ is considered as derived from decomposition of organic matter contained in the sediments, and involved into the hydrothermal fluid by various processes. Thermal degradation of organic matter has been considered as an important process to produce abundant $\mathrm{CH}_{4}$ (e.g., Cruse and Seewald 2006), while Kawagucci et al. (2013) recently demonstrated microbial methanogenesis within the fluid recharge region could supply abundant $\mathrm{CH}_{4}$. In either case, other organic matter-derived species such as $\mathrm{NH}_{4}{ }^{+}$and $\mathrm{HCO}_{3}{ }^{-}$can be abundantly involved into the hydrothermal fluid. These dissolved species would control $\mathrm{pH}$ of the fluid and may have high buffer potential in the low temperature condition during the mixing of the hydrothermal fluid and ambient seawater (Tivey et al. 1999).

$\mathrm{CH}_{4}$ is strong-reductive species, which can be utilized as energy source of electron donor for metabolic reactions. Aerobic and anaerobic methanotroph based-microbial ecosystem has been found in the Okinawa Trough, both as the symbiotic bacteria of Bathymodiolus and ANME-2 archaea which oxidizes $\mathrm{CH}_{4}$ anaerobically in collaboration with $\delta$ proteobacteria (Nakagawa et al. 2005).

\subsubsection{TAIGA of Sulfur}

Magmatic volatiles including $\mathrm{H}_{2} \mathrm{O}, \mathrm{CO}_{2}$, and $\mathrm{SO}_{2}$ are degassed from arc magma during its cooling process. It is known that $\mathrm{SO}_{2}$ reacts with water, causing a disproportionation reaction where $\mathrm{SO}_{2}$ dissociates into $\mathrm{H}_{2} \mathrm{~S}$ and $\mathrm{SO}_{4}$ at around $400{ }^{\circ} \mathrm{C}$ (Hedenquist 1995). Then, involvement of 
magma-derived $\mathrm{H}_{2} \mathrm{~S}$ volatiles into the hydrothermal fluid would act as an important source of reductive sulfur species. Supply of these magmatic volatiles into hydrothermal fluid is common for all the hydrothermal systems related to magma intrusion. However extent of their influence would be different according to the tectonic settings. While the magma in the mid-oceanic ridge is often depleted in the volatile species, magma in the arc-backarc setting is usually enriched in the volatile species reflecting involvement of subducted materials during magma generation process. Moreover, redox state of silicic magma and mafic magma is controlled by different buffer systems, which would affect redox state of the volatile species composition.

In addition to $\mathrm{H}_{2} \mathrm{~S}$, various sulfur species with different redox states are known to occur in hydrothermal environment. There exists a diverse range of autotrophic microorganisms that can use these compounds for their metabolism. TAIGA of sulfur is expected to occur extensively in wide range of hydrothermal systems, which are hosted by felsic to mafic magmatism and devoid of organic matter-rich sediment. In such environment, other important reduced species, $\mathrm{H}_{2}$ and $\mathrm{CH}_{4}$ are not expected to be abundant in the hydrothermal fluid.

\subsubsection{TAIGA of Iron}

Furnes et al. (2001) proposed that microorganisms are the primary cause of the seafloor weathering of oceanic crusts as they dissolve the volcanic glass, produce hydrated shells, and form biofilms. Little is known about the nature of the microorganisms which cause this alteration, however there are cases where the iron oxidizing bacteria Gallionella has been found (Thorseth et al. 1995). In aged seafloor basalts, elevated cell density and highly diverse microbial community has been found (e.g. Santelli et al. 2008).

Aerobic oxidation of ferrous iron in the oceanic crust could be one of important energy sources for the microbial ecosystem if it becomes accessible for use. Since iron is the fourth most plentiful element on the Earth, the subseafloor biosphere supported by TAIGA of iron could be extensive if iron works for electron donor for the microbial ecosystem. Bach and Edwards (2003) estimated available energy from reduced iron species in the oceanic crust and proposed that microbial activity which depends on alteration (weathering) of basalt can exist within the pore spaces of the oceanic crust of the age younger than $10 \mathrm{Ma}$, although their activity is difficult to detect.

Distal part of an active hydrothermal system hosted by basaltic lava could provide a good test field to study the TAIGA of iron, because low temperature acidic hydrothermal fluids may extract ferrous ion from basalt and supply it in an accessible form to the microbial ecosystems.

\section{$1.4 \quad$ Interdisciplinary Studies During TAIGA Project}

Three integrated study areas were established to investigate the representative fields for the four types of TAIGAs. The first target area is the Central Indian Ridge for the "TAIGA of hydrogen". This is because the Rodrigues Triple Junction at the southern Central Indian Ridge is the place where the first hydrogen-based chemoautotrophic microorganisms were reported (Takai et al. 2004a). We located another "TAIGA of hydrogen" near there during the project. The second target area is the South Mariana Trough. In this region, four active hydrothermal fields had been located (Kakegawa et al. 2008), and they are expected to represent "TAIGA of sulfur", as geophysical studies revealed excess magmatic supply in this region. Moreover, low temperature hydrothermal activities are expected to represent "TAIGA of iron" since abundant fresh basalt lava flow and strongly acidic hydrothermal fluids have been observed in this region. The third target area is Okinawa Trough. In this region, more than five active hydrothermal fields had been located in sedimented backarc rift. These hydrothermal activities are expected to represent "TAIGA of methane". They are found in caldera-like volcanic depressions or volcanic knolls related to arc/backarc volcanic activity which is covered with thick terrigenous and/or volcanic sediments. These sediments include substantial amount of organic material which were derived from Asian continent. Integrated Ocean Drilling Program (IODP) Expedition 331 drilled this target to investigate the deep structure of the hydrothermal system in 2010. Besides, shallow coring expedition was performed using Benthic Multicoring System (BMS) on-board the R/V Hakurei-Maru No. 2.

As a matter of course, these three targets never be able to represent entire variety of hydrothermal activities and the associated chemical signature found on global deepsea floor. However, the integrated research on these characteristic examples will provide us not only the biogeochemical nature of the venting fluids but also entire image of the hydrothermal systems that produce the fluids as the consequence of interaction between the solid and fluid earth. The combination of the results on the elementary steps of microbial metabolism, geochemical cycles, and tectonic framework of the advection will enhance our understanding and allow us to make overall estimation of the deep biosphere.

Therefore, we conducted a variety of physical, chemical and (micro)biological approaches were taken on these four TAIGAs to examine the wholistic views of these regions. Fundamental micro-scales of interaction processes between solid (rocks and minerals), fluid (water, solutes and gas) and 
life (microbial communities) were clarified by in situ, onboard and onshore observations, analyses and experiments. A link between the geophysical and geochemical structure around vent sites and the hydrothermal ecosystem were studied by surface mapping, OBS/OBEMs deployment experiments, and petrochemical studies of collected rocks and ores. Biogeochemical impacts of TAIGA discharge to the surrounding marine environments were revealed by comprehensive investigation of geophysical, geochemical, and microbiological phenomena in hydrothermal plumes. In addition to these field studies, experimental studies aimed to reproduce chemical and microbiological process in the TAIGA steps using high-pressure and hightemperature experimental apparatus were conducted. Furthermore, two different methodologies were developed with a view to estimate ages of hydrothermal events and phenomena; application of geochronological techniques to hydrothermal minerals and systematic analysis of phylogenetic relationships among animal species in hydrothermal vent fields.

As a conclusion, we would like to point out that our "TAIGA hypothesis" was proven to be valid which you will see in this book. It is also shown that the chemosynthetic metabolism based on sulfur species is always important even within the TAIGA of hydrogen or the TAIGA of methane. In fact, it is known that the most active microbial communities at high-temperature hydrothermal vents, regardless of the tectonic location, are bacteria which oxidize and reduce various sulfur species (Nakagawa et al. 2006; Takai et al. 2008a and the references therein).

In this e-book, readers will find wide variety of results from these interdisciplinary studies. The main reason why we choose this publication form is to provide the readers with comprehensive views of these target regions: Wide ranges of topics both on the arc-backarc systems in western Pacific and on mid-ocean ridge system of the Indian Ocean were covered, which are compared with each other based on the idea of four types of TAIGAs. We believe this e-book provide a good base for discussion on linkage between the subseafloor biosphere and hydrosphere with global perspective.

Acknowledgements We would like to express our appreciation to Ministry of Education, Culture, Sports, Science and Technology in Japan for funding this project from FY2008 to FY2012 (\#2010900120109006), as a project of Grant-in-Aid for Scientific Research on Innovative Areas.

Open Access This chapter is distributed under the terms of the Creative Commons Attribution Noncommercial License, which permits any noncommercial use, distribution, and reproduction in any medium, provided the original author(s) and source are credited.

\section{References}

Alt JC (2003) Hydrothermal fluxes at mid-ocean ridges and on ridge flanks. C R Geosci 335:853-864

Bach W, Edwards KJ (2003) Iron and sulfide oxidation within the basaltic ocean crust: implications for chemolithoautotrophic primary biomass production. Geochim Cosmochim Acta 67:3871-3887

Bach W, Peuker-Ehrenbrink B, Hart SR, Blusztajn JS (2003) Geochemistry of hydrothermally altered oceanic crust: DSDP/ODP Hole 504B - implications for seawater- crust exchange budgets and $\mathrm{Sr}-$ and $\mathrm{Pb}$-isotopic evolution of the mantle. Geochem Geophys Geosyst 4:8904

Baker ET, Embley RW, Walker SL, Resing JA, Lupton JE, Nakamura K-I, de Ronde CEJ, Massoth GJ (2008) Hydrothermal activity and volcano distribution along the Mariana arc. J Geophys Res 113: B08S09

Charlou JL, Donval JP, Fouquet Y, Jean-Baptiste P, Holm N (2002) Geochemistry of high $\mathrm{H}_{2}$ and $\mathrm{CH}_{4}$ vent fluids issuing from ultramafic rocks at the rainbow hydrothermal field $\left(36^{\circ} 14^{\prime} \mathrm{N}, \mathrm{MAR}\right)$. Chem Geol 191:345-359

Childress JJ, Fisher CR (1992) The biology of hydrothermal vent animals; physiology, biochemistry and autotrophic symbioses. Oceanogr Mar Biol 30:337-441

Cruse AM, Seewald JS (2006) Geochemistry of low-molecular weight hydrocarbons in hydrothermal fluids from Middle Valley, northern Juan de Fuca Ridge. Geochim Cosmochim Acta 70:2073-2092

Deming JW, Baross JA (1993) Deep-sea smokers: windows to a subsurface biosphere? Geochim Cosmochim Acta 57:3219-3230

Elderfield H, Schultz A (1996) Mid-ocean ridge hydrothermal fluxes and the chemical composition of the ocean. Ann Rev Earth Planet Sci 24:191-224

Fisher AT, Davis EE, Hutnak M, Spiess V, Zuhlsdorff L, Cherkaoul A, Christiansen L, Edwards K, Macdonald R, Villinger H, Mottl MJ, Wheat CG, Becker K (2003) Hydrothermal recharge and discharge across $50 \mathrm{~km}$ guided by seamounts on a young ridge flank. Nature 421:618-621

Fisher CR, Takai K, Le Bris N (2007) Hydrothermal vent ecosystems. Oceanography 20:14-25

Furnes H, Staudigel H, Thorseth IH, Torsvik T, Muehlenbachs K, Tumyr O (2001) Bioalteration of basaltic glass in the oceanic crust. Geochem Geophys Geosyst 2:2000GC000150

Gamo T, Ishibashi J, Tsunogai U, Okamura K, Chiba H (2006) Unique geochemistry of submarine hydrothermal fluids from arc-backarc settings of the western Pacific. In: Christie DM, Fisher CR, Lee S-M, Givens S (eds) Back-arc spreading systems: geological, biological, chemical, and physical interactions. AGU monograph series, vol 166, American Geophysical Union, Washington, DC, pp 147-161

Ge S, Bekins B, Bredehoeft J, Brown K, Davis EE, Gorelick SM, Henry P, Kooi H, Moench AF, Ruppel C, Sauter M, Screaton E, Swart PK, Tokunaga T, Voss CI, Whitaker F (2003) Fluid flow in sub-seafloor processes and future ocean drilling. Eos Trans Am Geophys Union 84:145-152

Hedenquist JW (1995) The ascent of magmatic fluid: discharge versus mineralization. in Magmas. In: Thompson JFH (ed) Fluids, and ore deposits, Mineralogical Association of Canada, Short Course, vol 23, Mineralogical Association of Canada, Nepean, Ontario, Canada, pp 263-290

Hirose T, Kawagucci S, Suzuki K (2011) Mechanoradical $\mathrm{H}_{2}$ generation during simulated faulting: implications for an earthquakedriven subsurface biosphere. Geophys Res Lett 38, L17303 
Johnson HP, Pruis MJ (2003) Flux of fluid and heat from the oceanic crustal reservoir. Earth Planet Sci Lett 216:565-574

Johnson HP, Baros JA, Bjorklund TA (2006) On sampling the upper crustal reservoir of the NE Pacific Ocean. Geofluids 6:251-271

Kakegawa T, Utsumi M, Marumo K (2008) Geochemistry of sulfide chimneys and basement pillow lavas at the Southern Mariana Trough $\left(12.55^{\circ} \mathrm{N}-12.58^{\circ} \mathrm{N}\right)$. Resour Geol 58:249-266

Kawagucci S, Ueno Y, Takai K, Toki T, Ito M, Inoue K, Makabe A, Yoshida N, Muramatsu Y, Takahata N, Sano Y, Narita T, Teranishi G, Obata H, Nakagawa S, Nunoura T, Gamo T (2013) Geochemical origin of hydrothermal fluid methane in sediment-associated fields and its relevance to the geographical distribution of whole hydrothermal circulation. Chem Geol 339:213-225

Kelley DS, Baross JA, Delaney JR (2002) Volcanoes, fluids, and life at mid-ocean ridge spreading centers. Ann Rev Earth Planet Sci 30: 385-491

McCollom TM, Seewald JS (2001) A reassessment of the potential for reduction of dissolved $\mathrm{CO}_{2}$ to hydrocarbons during serpentinization of olivine. Geochim Cosmochim Acta 65:3769-3778

McCollom TM, Shock EL (1997) Geochemical constraints on chemolithoautotrophic metabolism by microorganisms in seafloor hydrothermal systems. Geochimica et Cosmochimica Acta 61: 4375-4391

Mottl ML (2003) Partitioning of energy and mass fluxes between midocean ridge axes and flanks at high and low temperature. In: Halbach PE (ed) Energy and mass transfer in marine hydrothermal systems. Dahlem University Press, Berlin, pp 271-286

Mottl MJ, Wheat CG, Baker E, Becker N, Davis E, Feely R, Grehan A, Kadko D, Lilley M, Massoth G, Moyer C, Sansone F (1998) Warm springs discovered on 3.5 Ma oceanic crust, eastern flank of the Juan de Fuca Ridge. Geology 26:51-54

Mottl MJ, Glazer BT, Kaiser RI, Meech KJ (2007) Water and astrobiology. Chemie der Erde 67:253-282

Nakagawa S, Takai K, Inagaki F, Chiba H, Ishibashi J-I, Kataoka S, Hirayama H, Nunoura T, Horikoshi K, Sako Y (2005) Variability in microbial community and venting chemistry in a sediment-hosted backarc hydrothermal system: impacts of subseafloor phaseseparation. FEMS Microbiol Ecol 54:141-155

Nakagawa T, Takai K, Suzuki Y, Hirayama H, Konno U, Tsunogai U, Horikoshi K (2006) Geomicrobiological exploration and characterization of a novel deep-sea hydrothermal system at the TOTO caldera in the Mariana Volcanic Arc. Environ Microbiol 8:37-49

Nakamura K, Morishita T, Bach W, Klein F, Hara K, Okino K, Takai K, Kumagai H (2009) Serpentinized troctolites exposed near the Kairei hydrothermal field Central Indian Ridge: insights into the origin of the Kairei hydrothermal fluid supporting a unique microbial ecosystem. Earth Planet Sci Lett 280:128-136

Petersen JM, Zielinski FU, Pape T, Seifert R, Moraru C, Amann R, Hourdez S, Girguis PR, Wankel SD, Barbe V, Pelletier E, Fink D, Borowski C, Bach W, Dubilier N (2011) Hydrogen is an energy source for hydrothermal vent symbioses. Nature 476:176-180

Santelli CM, Orcutt BN, Banning E, Bach W, Moyer GL, Sogin ML, Staudigel H, Edwards KJ (2008) Abundance and diversity of microbial life in ocean crust. Nature 453:653-656
Seyfried Jr WE, Foustoukos DI, Allen DE (2004) Ultramafic-hosted hydrothermal systems at mid-ocean ridges: chemical and physical controls on $\mathrm{pH}$, redox and carbon reduction reactions. In: German $\mathrm{C}$, Lin $\mathrm{J}$ (eds) Mid-ocean ridges: hydrothermal interactions between the lithosphere and oceans, American Geophysical Union Geophysical Monograph Series, vol. 148, American Geophysical Union, Washington, DC, pp 267-284

Stein CA, Stein S (1992) A model for the global variation in oceanic depth and heat flow with lithospheric age. Nature 359:123-137

Stevens TO, McKinley JP (1995) Lithoautotrophic microbial ecosystems in deep basalt aquifers. Science 270:450-454

Takai K, Horikoshi K (1999) Genetic diversity of Archaea in deep-sea hydrothermal vent environments. Genetics 152:1285-1297

Takai K, Gamo T, Tsunogai U, Nakayama N, Hirayama H, Nealson K, Horikoshi K (2004a) Geochemical and microbiological evidence for a hydrogen-based, hyperthermophilic subsurface lithoautotrophic microbial ecosystem (HyperSLiME) beneath as active deep-sea hydrothermal field. Extremophiles 8:269-282

Takai K, Nealson KH, Horikoshi K (2004b) Methanotorris formicicus sp. nov., a novel extremely thermophilic, methane-producing archaeon isolated from a black smoker chimney in the Central Indian Ridge. Int J Syst Evol Microbiol 54:1095-1100

Takai K, Hirayama H, Nakagawa T, Suzuki Y, Nealson KH, Horikoshi K (2005) Lebetimonas acidiphila gen. nov., sp. nov., a novel thermophilic, acidophilic, hydrogen-oxidizing chemolithoautotroph within the 'Epsilonproteobacteria', isolated from a deep-sea hydrothermal fumarole in the Mariana Arc. Int J Syst Evol Microbiol 55:183-189

Takai K, Nunoura T, Ishibashi J, Lupton J, Suzuki R, Hamasaki H, Ueno Y, Kawagucci S, Gamo T, Suzuki Y, Hirayama H, Horikoshi K (2008a) Variability in the microbial communities and hydrothermal fluid chemistry at the newly discovered Mariner hydrothermal field, southern Lau Basin. J Geophys Res 113, G02031

Takai K, Nakamura K, Toki T, Tsunogai U, Miyazaki M, Miyazaki J, Hirayama H, Nakagawa S, Nunoura T, Horikoshi K (2008b) Cell proliferation at $122{ }^{\circ} \mathrm{C}$ and isotopically heavy $\mathrm{CH}_{4}$ production by a hyperthermophilic methanogen under high-pressure cultivation. Proc Natl Acad Sci USA 105:10949-10954

Thorseth IH, Torsvik T, Furnes H, Muehlenbachs K (1995) Microbes play an inportant role in the alteration of oceanic crust. Chem Geol 126:137-146

Tivey MK, Stakes DS, Cook TL, Hannington MD, Petersen S (1999) A model for growth of steep-sided vent structures on the endeavour segment of the Juan de Fuca Ridge: results of a petrologic and geochemical study. J Geophys Res 104:22859-22883

Toki T, Tsunogai U, Ishibashi J, Utsumi M, Gamo T (2008) Methane enrichment in low-temperature hydrothermal fluids from the Suiyo Seamount in the Izu-Bonin Arc of the western Pacific Ocean. J Geophys Res 113:B08S13

Wheat CG, Mottl MJ (2004) Geochemical fluxes through ridge flanks. In: Davis EE, Elderfield H (eds) Hydrolgeology of the oceanic lithosphere. Cambridge University Press, Cambridge, pp 627-658 